PRODUCTION

ENGINEERING

ARCHIVES
2016, Vol. 10, No 1, pp 9-12

ISSN 2353-5156

ISSN 2353-7779 (print version)

(online version)

Article history: $\quad$ Received: 10.01 .2016

\title{
Quality and fatigue characteristics relation
}

\author{
Libor Trško ${ }^{1}$, Otakar Bokůvka ${ }^{2}$, František Nový ${ }^{3}$, Ján Lago $^{4}$ \\ ${ }^{1}$ Ing., PhD., Research Centre of the University of Žilina, SK, phone: +421415132607, e-mail: libor.trsko@rc.uniza.sk \\ ${ }^{2}$ Prof. Ing.PhD.,University of Žilina, Department of Materials Engineering, SK, phone: +421415132603 , \\ e-mail: otakar.bokuvka@fstroj.uniza.sk \\ ${ }^{3}$ Ing. PhD., University of Žilina, Department of Materials Engineering and Research Centre of University of Žilina, SK, \\ phone: +421415132607, e-mail: frantisek.novy@fstroj.uniza.sk \\ ${ }^{4}$ Ing., University of Žilina, Department of Materials Engineering, SK, phone: +421415132624, e-mail: jan.lago@fstroj.uniza.sk
}

\begin{abstract}
This paper will explore the mutual correlation of fatigue characteristics $\left(\left(\mathrm{K}_{\mathrm{ath}}, \sigma_{\mathrm{c}}, \mathrm{a}_{\mathrm{c}}=\mathrm{f}\left(\mathrm{R}_{\mathrm{m}}\right)\right)\right.$ of five structural steels tested at highfrequency loading based on tests $\left(\mathrm{f} \approx 20 \mathrm{kHz}, \mathrm{T}=20 \pm 10^{\circ} \mathrm{C}, \mathrm{R}=-1\right)$. Different fatigue resistance parameters have different meanings and misunderstanding can lead to significant quality problems in component operation. Consequently, it is necessary to completely understand the relation between the two most important fatigue characteristics which are fatigue limit $\sigma_{\mathrm{c}}$ and the threshold value of the stress intensity factor amplitude $\mathrm{K}_{\mathrm{ath}}$ and how they act with changing of steel ultimate tensile strength.
\end{abstract}

Key words- structural steels, fatigue, $K_{a t h}, \sigma_{c}, a_{c}$, fatigue parameters relation

\section{Introduction}

Degradation of structural materials properties caused by fatigue is a serious problem in engineering applications, because more than $90 \%$ of all fractures which occur during the operation of a component are caused by fatigue (BOKUீVKA O. et. al. 2015). Fatigue of structural materials has therefore been studied intensively in the past 170 years (BOKUீVKA O. et. al. 2002, KUNZ L. 2003, ULEWICZ R. 2013).

Fatigue life of a component or a construction (number of cycles N) contains a number of cycles necessary for fatigue crack initiation $\mathrm{Ni}$ and a number of cycles necessary for crack propagation $\mathrm{N}_{\mathrm{p}}$. Components or constructions in term of their resistance to fatigue damage can be evaluated using two methods, that is according to total lifetime (number of cycles $\mathrm{N}$ where $\mathrm{N}=\mathrm{N}_{\mathrm{i}}+\mathrm{N}_{\mathrm{p}}$ ) or according to fatigue crack propagation with respect to laws of fracture mechanics (according to number of cycles necessary for crack propagation $\mathrm{N}_{\mathrm{p}}$ ), (SKOČOVSKÝ P. et. al. 2015, TRŠKO L. et. al. 2013).

When evaluating the material resistance according to total lifetime method, the dependence of stress amplitude $\sigma_{\mathrm{a}}$ (for high cycle fatigue) on number of cycles to failure or run - out $\mathrm{N}$ is evaluated. High cycle fatigue is characterized by Wöhler diagram, $\sigma_{a}=f(N)$. From the Wöhler diagram fatigue limit $\sigma_{c}$. Fatigue limit $\sigma_{c}$ can be evaluated and is the highest amplitude of alternating stress at a certain mean stress $\sigma_{\mathrm{m}}$ which can theoretically withstand for an infinite number of cycles. During fatigue tests it is impossible to load the specimen for an infinite number of cycles. In practical usage the material has a good resistance to fatigue if it can withstand the basic number of cycles Nc, which is in standards for steels $-\mathrm{N}_{\mathrm{c}}=10^{7}$ cycles.

When evaluating the material resistance according to fatigue crack propagation, the dependence of the 
fatigue crack growth rate $\mathrm{da} / \mathrm{dN}$ on the stress intensity factor amplitude $\mathrm{K}_{\mathrm{a}}$ is evaluated. From the $\mathrm{da} / \mathrm{dN}=\mathrm{f}\left(\mathrm{K}_{\mathrm{a}}\right)$ the threshold value of the stress intensity factor amplitude $K_{\text {ath }}$ can be evaluated which represents the resistance of material against the crack growth. It is determined according to interatomic distance (crystallography lattice parameter). If the crack increase for one cycle is smaller than one interatomic distance, than cyclic loading has no degradation effect from a physical point of view (it does not cause a macroscopic growth of fatigue crack). In application it means that for values $\mathrm{K}_{\mathrm{a}} \leq \mathrm{K}_{\mathrm{ath}}$ cracks don't grow or growth is extremely slow (slower than $\mathrm{da} / \mathrm{dN}=10^{-10}$ m.cycle ${ }^{-1}$ ) and it does not cause breaking of material by fatigue fracture for expected time of using (KLESNIL M. 1975, SKOČOVSKÝ P. et. al. 2006).

If it is assumed that structural material will be in operation subjected to fatigue cyclic loading, then it is important to evaluate complex fatigue characteristics for the exact kind of working conditions. This means obtaining the exact values of fatigue limit $\sigma_{\mathrm{c}}$ for given structural material and threshold value of the stress intensity factor amplitude $\mathrm{K}_{\mathrm{ath}}$; but is also very important to know the correlation between $\sigma_{\mathrm{c}}$ and $\mathrm{K}_{\text {ath }}$. Knowledge of material constants and their relation is essential for proper design of machine components and their safety and reliability (HuRTAlovÁ L. et al. 2013).

In this work the authors, on the basis of these results, discuss the mutual relationship between the threshold value of the stress intensity factor amplitude $\mathrm{K}_{\text {ath }}$ and fatigue limit $\sigma_{\mathrm{c}}$.

\section{Experimental}

The experimental works, quantitative chemical analysis, tensile tests and fatigue tests were carried out on five structural steels. The tensile tests were carried out on a ZWICK Z050 testing machine at an ambient temperature of $\mathrm{T}=20 \pm 5^{\circ} \mathrm{C}$, with the loading range in interval $\mathrm{F}=0 \div 20 \mathrm{kN}$ and the strain velocity range of $\varepsilon_{\mathrm{m}}=10^{-3} \mathrm{~s}^{-1}$. Round cross-section specimens were used; the shape and dimensions of the test specimens fulfilled the requirements of EN 10002-1 standard. Three specimens of each material were used.

The fatigue crack growth tests were carried out on a KAUP-ŽU resonance testing device, Fig. 1. The resonance fatigue testing device consists of ultrasonic generator, piezoelectric transducer, booster, exponential concentrator and a test specimen. The electric power from ultrasonic generator is transferred to mechanical vibration in the piezo-ceramic converter of the ultrasonic horn. This causes vibration at both ends of the specimen at resonance frequency. The power is increased until requested displacement amplitude is obtained (measured by deformation amplitude reader on the end of the specimen). A resonance fatigue testing machine allows fatigue tests to be performed with symmetrical push-pull loading $(\mathrm{R}=-1)$ at a frequency of $\mathrm{f} \approx 20 \mathrm{kHz}$ in the temperature interval of $\mathrm{T}=20 \pm 5$ ${ }^{\circ} \mathrm{C}$.

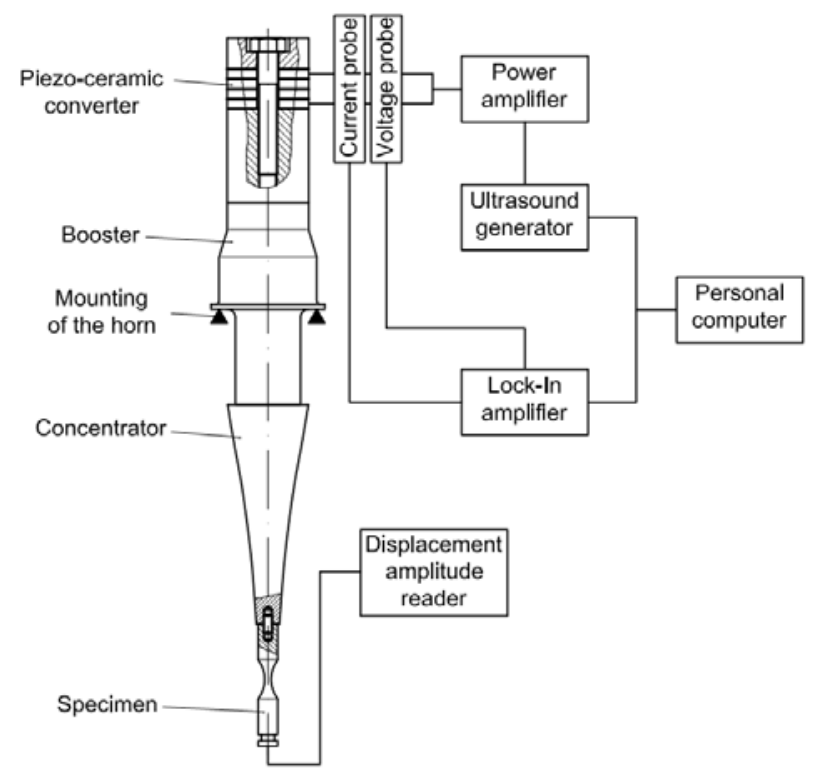

Fig.1. Schematic diagram of the construction of KAUP-ŽU fatigue testing device

Source: own study

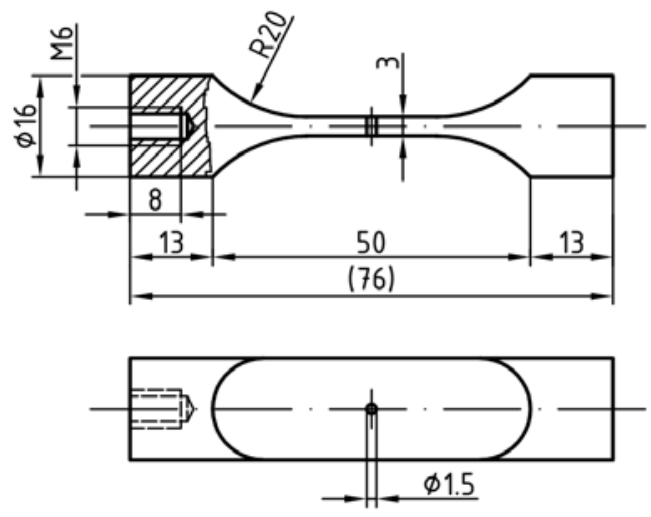

Fig. 2. The shape and dimensions of the fatigue crack growth test specimen

Source: own study 


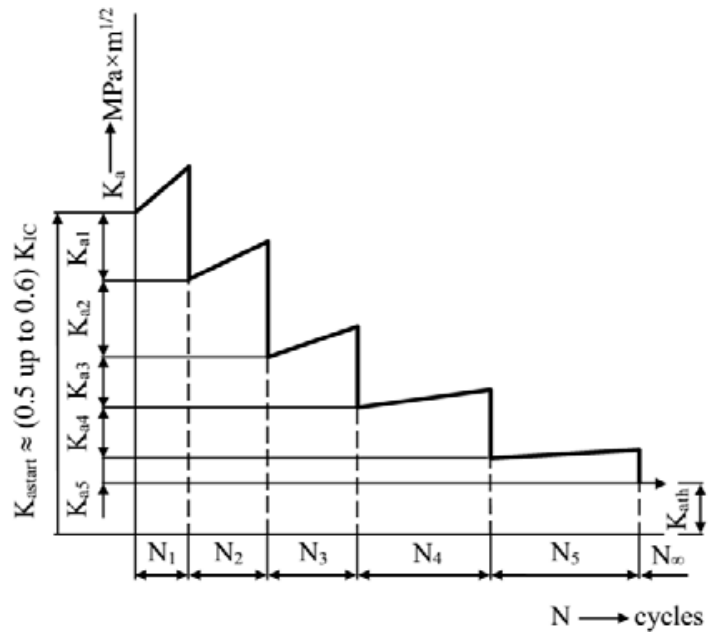

Fig. 3. The method to determine $K_{a t h}$ by gradual decreasing of $K_{a}$ value until the fatigue crack growth is terminated

Source: own study

The shape and dimensions of specimens used in the fatigue crack growth tests are given in Fig. 2. The procedure for evaluation of $\mathrm{K}_{\text {ath }}$ values result from Fig. 3. This method is based on gradual decreasing of the loading value until the crack stops propagating. The test can be controlled by the decrease of the loading force or by decrease of the K-factor. After each step (each decrease of the loading force or K-factor) the crack has to grow through the plastically deformed zone together with the zone of residual stresses, which were created by the previous loading values. The crack stops its propagation when the threshold value is reached. The applied stress intensity factor amplitude $\mathrm{K}_{\mathrm{a}}$ was determined using the following equation:

$$
k_{\mathrm{a}}=\sigma_{\mathrm{a} \cdot} \cdot\left(\mathrm{w} \cdot \tan \quad \mathrm{MPa} \cdot \mathrm{m}^{1 / 2}\right.
$$

in which $\sigma_{a}$ is stress amplitude (MPa), $a$ is the half crack length (m) and $w$ is the specimen width (m), (KLESNIL M. 1975, PUŠKÁR A. et. al. 1987). The value of $\mathrm{K}_{\text {ath }}$ was determined at da $/ \mathrm{dN}=10^{-12} \mathrm{~m} \cdot$ cycle $^{-1}$; three specimens of each tested material were used.

\section{Results and discussion}

The results of quantitative chemical analysis (chemical composition) and tensile tests (ultimate tensile strength $R_{m}$ ) of five tested structural steels are in Table 1.

The results of fatigue tests at high-frequency fatigue loading, the threshold values $\mathrm{K}_{\mathrm{ath}}$, fatigue limit $\sigma_{\mathrm{c}}$ and half cracks length $\mathrm{a}_{\mathrm{c}}$ of fifth tested structural steels are shown in Table 2.
Tab. 1. Chemical composition (in weight \%) and tensile strength $R_{m}$ of tested steels

\begin{tabular}{|c|c|c|c|c|c|c|c|c|c|c|c|}
\hline $\begin{array}{c}\begin{array}{c}\text { Ele- } \\
\text { ment }\end{array} \\
\text { Steel }\end{array}$ & C & $\begin{array}{c}\mathrm{M} \\
\mathrm{n}\end{array}$ & $\mathrm{Si}$ & $\mathrm{P}$ & S & $\mathrm{Cr}$ & $\begin{array}{c}\mathrm{M} \\
\mathrm{o}\end{array}$ & $\mathrm{Ni}$ & $\begin{array}{l}\mathrm{C} \\
\mathrm{u}\end{array}$ & $\mathrm{V}$ & $\begin{array}{l}\mathrm{R}_{\mathrm{m}} \\
(\mathrm{M} \\
\mathrm{Pa})\end{array}$ \\
\hline 1 & $\begin{array}{c}0 . \\
26\end{array}$ & $\begin{array}{c}0 . \\
96\end{array}$ & $\begin{array}{c}0 . \\
35\end{array}$ & $\begin{array}{l}0.0 \\
19\end{array}$ & $\begin{array}{c}0.0 \\
2\end{array}$ & $\begin{array}{c}0 . \\
07\end{array}$ & - & $\begin{array}{c}0 . \\
02\end{array}$ & $\begin{array}{c}0 . \\
05\end{array}$ & - & 560 \\
\hline 2 & $\begin{array}{c}0 . \\
52\end{array}$ & $\begin{array}{c}0 . \\
80\end{array}$ & $\begin{array}{c}0 . \\
40\end{array}$ & $\begin{array}{l}0.0 \\
40\end{array}$ & $\begin{array}{c}0.0 \\
4\end{array}$ & $\begin{array}{l}0 \\
3\end{array}$ & $\begin{array}{c}0 . \\
05\end{array}$ & $\begin{array}{l}0 \\
3\end{array}$ & $\begin{array}{l}0 . \\
3\end{array}$ & $\begin{array}{c}0 . \\
05\end{array}$ & 841 \\
\hline 3 & $\begin{array}{c}0 . \\
78\end{array}$ & $\begin{array}{c}1 . \\
25\end{array}$ & $\begin{array}{c}0 . \\
70\end{array}$ & $\begin{array}{l}0.0 \\
15\end{array}$ & $\begin{array}{l}0.0 \\
22\end{array}$ & $\begin{array}{l}1 . \\
1\end{array}$ & - & - & - & - & $\begin{array}{c}109 \\
7\end{array}$ \\
\hline 4 & $\begin{array}{c}0 . \\
52\end{array}$ & $\begin{array}{c}0 . \\
6\end{array}$ & $\begin{array}{l}1 . \\
44\end{array}$ & $\begin{array}{c}0.0 \\
2\end{array}$ & $\begin{array}{l}0.0 \\
24\end{array}$ & $\begin{array}{c}0 . \\
57\end{array}$ & - & - & - & - & $\begin{array}{c}145 \\
2\end{array}$ \\
\hline 5 & $\begin{array}{c}0 . \\
54\end{array}$ & $\begin{array}{c}0 . \\
61\end{array}$ & $\begin{array}{c}1 . \\
41\end{array}$ & $\begin{array}{l}0.0 \\
19\end{array}$ & $\begin{array}{c}0.0 \\
04\end{array}$ & $\begin{array}{c}0 . \\
57\end{array}$ & - & - & - & - & $\begin{array}{c}153 \\
2\end{array}$ \\
\hline
\end{tabular}

Source: own study

Tab. 2. Threshold values $K_{\text {ath }}$, fatigue limit $\sigma_{c}$ and half cracks length $a_{c}$ of tested steel

\begin{tabular}{c|ccc}
\hline Steel & $\begin{array}{c}\mathrm{K}_{\text {ath }} \\
\left(\mathrm{MPa}^{1 / 2}\right)\end{array}$ & $\sigma_{\mathrm{c}}(\mathrm{MPa})$ & $\mathrm{a}_{\mathrm{c}}(\mathrm{mm})$ \\
\hline 1 & 4.50 & 196 & 0.1670 \\
2 & 3.38 & 294 & 0.0420 \\
3 & 2.80 & 383 & 0.0160 \\
4 & 2.28 & 508 & 0.0060 \\
5 & 2.10 & 536 & 0.0048 \\
\hline
\end{tabular}

Source: own study

The approximate fatigue limit $\sigma_{\mathrm{c}}$ was calculated using the equation $\sigma_{c}=0.35 \mathrm{R}_{\mathrm{m}}$ (valid for structural steels with $R_{m}$ in interval from $R_{m}=500 \mathrm{MPa}$ to $R_{m}=$ $1500 \mathrm{MPa}$ ), with regards to the work (S̆IMEK V. 1969). A discussion of the tensile strength $R_{m}$ vs. threshold $\mathrm{K}_{\mathrm{ath}}$ and tensile strength $\mathrm{R}_{\mathrm{m}}$ vs. fatigue limit $\sigma_{\mathrm{c}}$ response incl. relation of threshold $\mathrm{K}_{\mathrm{ath}} \mathrm{vs}$. fatigue limit $\sigma_{\mathrm{c}}$ behavior was possible to describe by Fig. 4 where the $\mathrm{K}_{\text {ath }}$ values obtained in structural steels is decreasing with increasing of $R_{m}$ and on the other hand the $\sigma_{c}$ increasing with $R_{m}$ increase. The same trend was reported by authors (RITCHIE R. O. 1981, BOKŮVKA O. et. al. 1992), retardation effects to fatigue crack propagation have also been found to be highest in lowstrength steels (PETRAK G. J. 1974, BOKU゚VKA O. et. al. 2012). The microstructural factors (e. g. strength and grain size) indicate that thresholds for crack growth $\left(\mathrm{K}_{\text {ath }}\right)$ is decreased by high strength levels and fine grain sizes whereas thresholds for crack initiations, e. g. fatigue limit $\left(\sigma_{c}\right)$ are increased by high strength levels and fine grains sizes (RITCHIE R.O. 1981, BOKU゚VKA O. et. al. 2015). 
This means that with the increase of the ultimate tensile strength of structural material, the critical length of the crack which starts to propagate by fatigue mechanism decreases. This seems to be contrary to the values of the fatigue limit, which is higher for materials with higher tensile strength. It must be un-

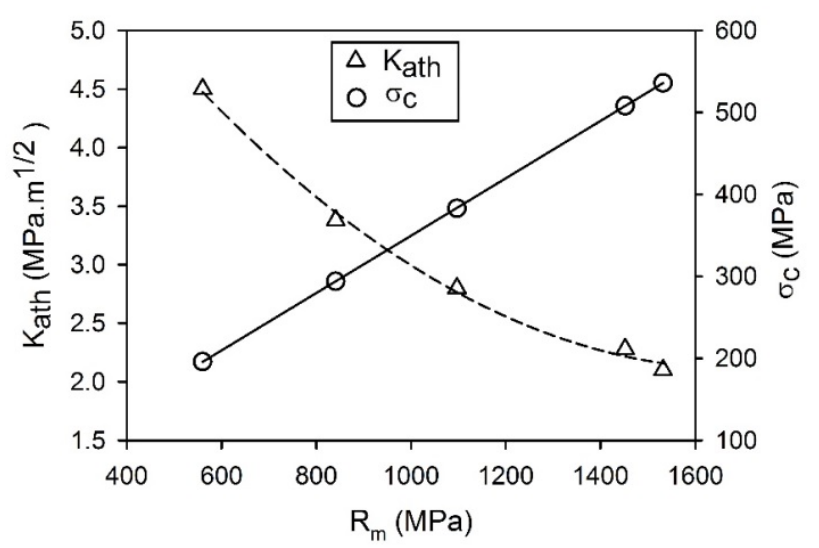

Fig. 4. $K_{\text {ath }}$ and $\sigma_{c}$ dependence on ultimate tensile strength $R_{m}$ Source: own study

derstood that the $\mathrm{K}_{\text {ath }}$ value is a parameter representing only the critical size of a crack or a defect from which the fatigue crack will propagate. If defects in material are smaller than the critical size, other fatigue crack initiation mechanism has to take place during the fatigue degradation process. Materials with higher ultimate tensile strength have higher resistance to fatigue crack initiation, but lower resistance to fatigue crack propagation. Because the fatigue crack initiation period represents more than $90 \%$ of the total number of cycles to fracture (this is related to smooth specimens and components without presence of defects and notches) and just the rest is needed for the fatigue crack propagation. Usually materials (mainly steels) with lower tensile strength are more ductile, thus they are able to create a plastically deformed zone in the surrounding of a crack tip. This deformed zone significantly slows down fatigue crack during its propagation and is the main reason why these materials have higher $\mathrm{K}_{\text {ath }}$ values. Again in the case of defects smaller than $\mathrm{K}_{\mathrm{ath}}$ the fatigue crack initiation process depends only on the strength of the material and these materials have a lower fatigue limit $\sigma_{c}$.

\section{Conclusions}

Based on fatigue crack growth, test results on five different structural steels with increasing ultimate tensile strength and their relation to approximate fatigue limit, it can be stated that with increasing materials ultimate tensile strength increases the fatigue limit $\sigma_{\mathrm{c}}$, and decreases the critical defect size represented by $\mathrm{K}_{\mathrm{ath}}$ value. In general, materials with higher strength are more resistant to fatigue loading but also more sensitive to various kinds of material defects (pores, inclusions etc.), surface defects (scratches, machining marks etc.) and artificial notches (sharp edges between different diameters, holes, grooves etc.). This means that the stronger the material used to improve the fatigue resistance of the component, the bigger the care necessary to take on the surface quality and construction of the component to avoid sharp notches.

\section{Acknowledgements}

The research was supported by Scientific Grand Agency of Ministry of Education, Science and Sport of Slovak Republic and Slovak Academy of Sciences, grant VEGA No. $1 / 0123 / 15$, by the project APVV-14-0096 and project "Research Centre of the University of Žilina", ITMS 26220220183.

\section{Bibliography}

1. BOKU゚VKA O. et al. 2002. Low and High Frequency Fatigue Testing. EDIS ŽU v Žiline.

2. BOKUீVKA O. et al. 2015. Fatigue of Materials at Low and High-frequency Loading. EDIS, ŽU v Žiline.

3. KUNZ L. 2003. Experimentálnistanoveniúnavovýchcharakteristikmateriálů. EDIS ŽU v Žiline (in Czech).

4. ULEWICZ R., MAZUR M. 2013. Production Engineering Archives, No. 1, 32.

5. SKOČOVSKÝ P. et al. 2015. Náuka o materiáli. EDIS ŽU v Žiline(in Slovak).

6. TRŠKO L. et al. 2013. Dynamics Strength and Fatigue Lifetime. EDIS ŽU v Žiline.

7. KLESNIL M., LUKÁŠ P. 1975. Únavakovovýchmateriálioprimechanickémnamáhání. ACADEMIA Praha (in Czech).

8. SKOČOVSKÝ P. et al. 2006. Náuka o materiáli pre odborystrojnicke. EDIS ŽU v Žiline (in Slovak).

9. HURTALOVÁ L. et al. 2013. Key Eng. Materials, Vol. 592-593, 433.

10. PUŠKÁR A. et al. 1987. Strojírenství, 2, 507 (in Slovak).

11. RITCHIE R.O. 1981. Application of Fracture Mechanics to Fatigue Crack Propagation. University of California.

12. BOKU゚VKA O. et al. 1992. In. Procs. Materials Development in Rail, Tire, Wing, Hull Transportation. AIM Milano, Italy.

13. PETRAK G.J. 1974. Eng. Fracture Mechanics, 6, 725.

14. BOKU゚VKA O. et al. 2012. Annals of Faculty Engineering Hunedoara - Int. Journal of Engineering, Vol. X, No. 2. 